\title{
ANALISIS KOMPUTASI TEGANGAN AKIBAT UJI JATUH BEBAS DENGAN KETINGGIAN 3 METER PADA KOMPOSIT YANG DIGUNAKAN SEBAGAI PELINDUNG DADA PENGENDARA SEPEDA MOTOR
}

\author{
Gunawan H. ${ }^{1}$, M. Sabri ${ }^{2}$, Ikhwansyah Isranuri ${ }^{3}$, Pramio G. Sembiring ${ }^{4}$, A. Husein Siregar ${ }^{5}$ \\ 1,2,3,4,5 Departemen Teknik Mesin, Fakultas Teknik Universitas Sumatera Utara \\ Email: Gunawan083@yahoo.com
}

\begin{abstract}
The goal of this research is to identify computationally the stress and force that occur in the motor bike body protector which created using composite material. This test is done using ANSYS software. Test is using explicit dynamic with the free-fall impact methods which make the speciment crashed to the anvil. From the test the impact force transmitted is $14.95 \mathrm{kN}$ and with the stress $0.014952 \mathrm{Mpa}$. Average impact force that occur is $29.18 \mathrm{Mpa}$ which is compared with the EN 1621-3 standarization limit which is $35 \mathrm{kN}$ in order to determine if this body protector is consentient with the standard.
\end{abstract}

\section{Kata Kunci: Free-fall Impact, Force Transmission, Composite Material}

\section{PENDAhUluan}

Pengendara sepeda motor memiliki kemungkinan untuk terjadi kecelakaan besar,oleh karena beberapa produsen mengeluarkan perlengkapan keamanan untuk mengurangi resiko akibat kecelakaan.Salah satu perlengkapan keamanan adalah pelindung dada komposit ini selain dapat berfungsi menghalangi badan pengendara dari angin juga dirancang untuk menahan gesekan dan tumbukan yang terjadi ketika kecelakaan.

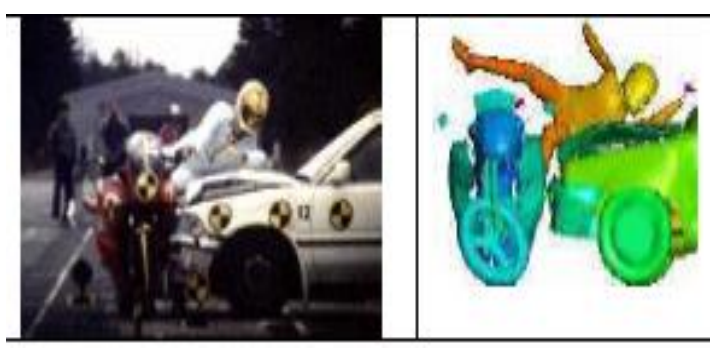

Gambar 1. Tabrakan dari samping sepeda motor dengan mobil [1].

Pelindung dada Ini dibuat dari bahan resin, serat kaca dan EVA foam (busa EVA). Komputasi dari pelindung dada ini bertujuan untuk mengetahui tegangan yang terjadi akibat tabrakan,yang diasumsi dengan kecelakaan yang terjadi.Komputasi ini menggunakan data yang didapat dari data proses pembuatan produk.Pelindung dada dibuat dengan material komposit GFRP(Glass Fibre Reinforced Polymer).Pada Tabel 1 dapat dilihat sifat dari material GFRP

Tabel 1. Sifat Material Komposit [5][6].

\begin{tabular}{lll}
\hline $\begin{array}{l}\text { Nama } \\
\text { Material }\end{array}$ & $\begin{array}{l}\text { Densitas } \\
\left(\mathrm{kg} / \mathrm{m}^{3}\right)\end{array}$ & $\begin{array}{l}\text { Modulus } \\
\text { Elastisitas } \\
(\mathrm{GPa})\end{array}$ \\
\hline $\begin{array}{l}\text { Polyester } \\
\text { Polymer }\end{array}$ & $\mathbf{1 0 0 4 - 1 4 0 0}$ & $\mathbf{2 , 0 7 - 4 , 4 1}$ \\
\hline
\end{tabular}




\begin{tabular}{lll}
\hline Busa Eva & $945-955$ & $0,01-0,04$ \\
GFRP & $1350-1500$ & $6-12$ \\
\hline
\end{tabular}

Analisa komputasi ini bertujuan mendapatkan tegangan yang terjadi pada pelindung dada pada saat pengujian jatuh bebas dengan ketinggian 3m.Tegangan yang didapat dibandingkan dengan standarisasi pelindung dada EN 1621-3.Standarisasi EN 1621 adalah standarisasi untuk peralatan keamanan pada pengendara sepeda motor.EN 1621-2 merupakan standarisasi merupakan standarisasi yang digunakan Velocity Gear [3]. CEN (Comite Europeen de Normalisation) adalah organisasi yang memimpin standar keamanan pakaian pelindung sepeda motor [4].

Tabel 2. Data Pengujian EN 1621-3 untuk

Chest Protector LEATT [2]

\begin{tabular}{|c|c|c|}
\hline $\begin{array}{l}\text { Gaya Impak } \\
\text { Transmisi }\end{array}$ & $\begin{array}{ll}\text { Syarat } & \text { EN } \\
1621-3 & \end{array}$ & $\begin{array}{l}\text { Pelindung } \\
\text { Dada } \\
\text { LEATT }\end{array}$ \\
\hline Mean kN & $<20$ & 12,1 \\
\hline $\operatorname{Max} \mathbf{k N}$ & $<35$ & 22,7 \\
\hline
\end{tabular}

Analisa ini menggunakan perangkat lunak ANSYS 14.1.Perangkat lunak ini memiliki basis perhitungan menggunakan persamaan Lagrangian, yang memilik ketelitian per variable yang tinggi [7][8].

$T=\sum_{i=1}^{k}\left[\frac{1}{2} m_{i}\left(\dot{x}_{1}^{2}+\dot{y}_{i}^{2}+\dot{z}_{i}^{2}\right]\right.$

Dimana :

$\mathrm{T}=$ gaya potensial

$m_{i}=$ massa

$\dot{x}_{1}^{2}=$ kecepatan pada koordinat $\mathrm{x}$

$\dot{y}_{i}^{2}=$ kecepatan pada koordinat $\mathrm{y}$

$\dot{z}_{i}^{2}=$ kecepatan pada koordinat $\mathrm{z}$

\section{METODOLOGI}

Penelitian ini dilaksanakan di Pusat Riset Impak dan Keretakan Jurusan Teknik Mesin Fakultas Teknik Universitas Sumatera Utara. Penelitian ini dimulai dengan pembuatan spesimen untuk pengujian impak jatuh bebas. Selanjutnya analisa data eksperimental menggunakan software DAQ For Helmet Impact Testing untuk mengolah data akusisi yang diperoleh dari Load cell. berikut:

Komputasi ini menggunakan software ANSYS 14.1.Penjelasan langkah komputasi sebagai

1. ANSYS Workbench 
Aktifkan menu ANSYS Workbench dengan klik icon ANSYS

Workbench pada program ANSYS. Pilih Explicit Dynamic (ANSYS) dari toolbox, dan double klik Explicit Dynamic lalu double klik pada project name dan beri judul sesuai dengan apa yang akan disimulasikan.

2. Engineering Data

Engineering data dapat diedit sesuai dengan masukan data yang kita inginkan dengan double klik pada Engineering Data atau dengan klik kanan pada bagian engineering data dan select edit. Dalam mengisi spesifikasi engineering data material double kilik pada "click here to add a new material" dan tulis nama material barunya seperti ini. Pada Toolbox sebelah kiri, double klik pada Physical Properties, kemudian double klik pada density lalu isikan nilai density materialnya. Selanjutnya pada toolbox sebelah kiri, double klik pada Linier Elatic, dan double klik pada Isotropic Elasticity dan isikan juga nilai modulus elastisitas dan poisson ratio. Setelah semua data diisi lalu beri tanda " $\sqrt{ }$ " dengan klik pada kolom $E$ lalu save. Setelah itu klik Icon "Return to Project" pada main menu.

3. ANSYS Design Modeler

Edit "Geometry" pada schematic project dengan double klik pada Geometry icon atau dengan klik kanan pada Geometry icon, pilih Import Geometry dan pilih menu Brows. Lalu pilih file name helmet dalam bentuk file standard Acis, lalu pilih Edit pada Sketching Toolboxes. Setelah itu Klik icon Generate pada modeling Tab.

4. Membuat Anvil Rata

Langkah ini dimulai dari new plane dengan tujuan untuk mengarahkan sumbu x,y,z plane ke arah sisi samping helmet, kemudian klik generate.

5. ANSYS Mechanical

Masuk ke ANSYS mechanical dengan cara double klik pada "model" pada project schemati. Untuk memilih data material, pilih selecting data dari "outline" three view, pilih created solid dan pilih material yang diinginkan dari "Detail of solid" window. Langkah selanjutnya, menentukan spesifikasi ukuran elemen dengan cara pilih Mesh dari "outline" tree view lalu klik kanan pada Mesh dan pilih Generate Mesh. Besar ukuran mesh akan diukur secara otomatis. Dan jika ukuran Mesh ingin dirubah pada bagian-bagian tertentu, dapat dilakukan dengan bantuan Refinement yang yang terdapat pada Mesh Control icon pada toolbar. Selanjutnya adalah Generate Mesh dengan cara klik Generate Mesh pada toolbar.

Langkah selanjutnya adalah penentuan kondisi batas atau "Boundary Conditon", klik fixed support dan klik pada bidang sisi bawah spesiman project. Langkah selanjutnya adalah pemberian gaya pada spesimen project dengan klik kanan Static Structural pada "outline" tree view, pilih insert dan klik Velocity dan klik pada bidang sisi tengah helmet dan masukkan nilai velocity yang diinginkan.

6. ANSYS Solver

Langkah selanjutnya adalah klik solve icon pada toolbar

7. ANSYS Post-Processor

Langkah selanjutnya adalah melihat besarnya deformasi yang terjadi pada spesimen project dengan klik kanan Solution "outline” tree view

,Insert pilih Equivalent Stress.

Data yang digunakan adalah data yang didapat dari percobaan yang dilakukan.Data yang digunakan sebagai berikut :
1. Densitas
$=1500 \mathrm{~kg} / \mathrm{m} 3$
2. Modulus Young $=12 \mathrm{GPa}$
3. Possion Ratio $=0,34$

Variabel penelitian komputasi ini adalah distribusi tegangan $(\sigma)$ yang terjadi pada permukaan pelindung dada sepeda motor setelah dikenai beban impak

\section{HASIL DAN PEMBAHASAN}

Pembebanan pada komputasi impak jatuh bebas ini diberikan pada depan pelindung dada. Ini karena bagian depan adalah bagian yang akan mendapatkan impak pada saat terjadi kecelakaan. Tujuan komputasi ini adalah membandingkan data hasil komputasi dengan data hasil eksperimental dan data 
standarisasi.Jenis spesimen yang dikomputasi adalah material komposit Glass Fibre Reinforced Polymer. Data material dari hasil eksperimental dapat dilihat pada Tabel 3:

Tabel 3 Spesifikasi Glass Fibre Reinforced Polymer yang Dikomputasi

\begin{tabular}{ccccc}
\hline Nama & Nama & \multicolumn{3}{c}{ Komposisi ( \% massa) } \\
\cline { 3 - 5 } Material & Spesimen & Resin & Katalis & Fibreglass \\
\hline $\begin{array}{c}\text { Glass } \\
\begin{array}{c}\text { Fibre } \\
\text { Reinforced } \\
\text { Polymer ( } \\
\text { GFRP ) }\end{array}\end{array}$ Fiber 1 & 77,6 & 2 & 20,4 \\
& Fiber 2 & 77,6 & 2 & 20,4 \\
& Fiber 3 & 77,6 & 2 & 20,4 \\
\hline
\end{tabular}

Maka dengan menggunakan data-data tabel 3 dilakukan komputasi.

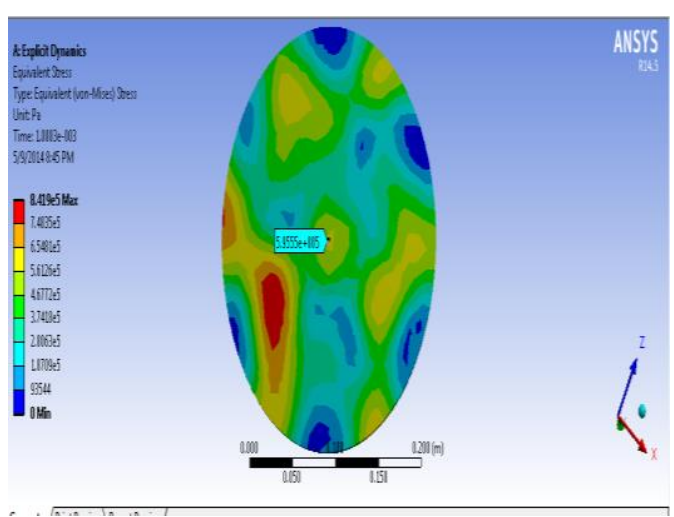

Gambar 2: Data Komputasi Impak Maksimum yang terjadi pada spesimen Glass Fibre Reinforced Polymer

Pada Gambar 2 menunjukkan tegangan maksimum yang terjadi pada spesimen glass fibre reinforced polymer pada waktu $1 \mathrm{~ms}$ akibat gaya impak uji jatuh bebas sebesar $595550 \mathrm{~Pa}$.

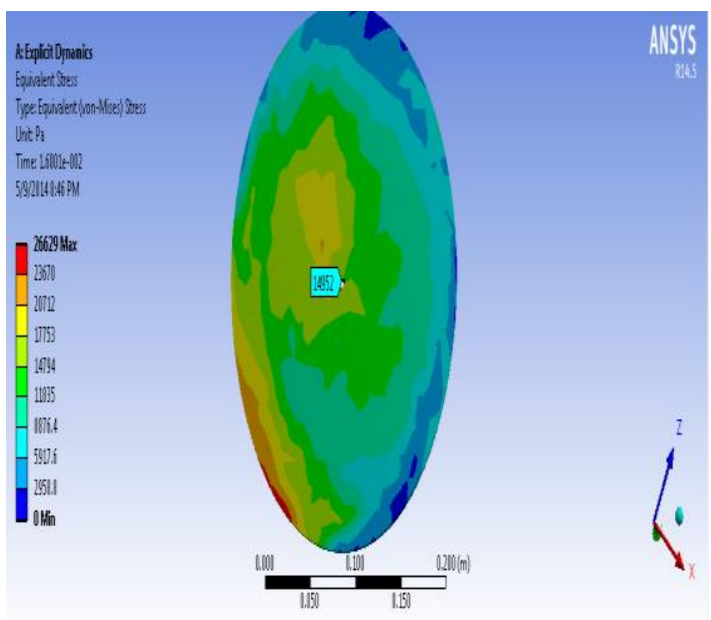

Gambar 3. Data Komputasi Impak yang 
terjadi pada spesimen Glass

Fibre Reinforced Polymer pada waktu $16 \mathrm{~ms}$

Pada Gambar 3 menunjukkan tegangan maksimum yang terjadi pada spesimen glass fibre reinforced polymer pada waktu $16 \mathrm{~ms}$ akibat gaya impak uji jatuh bebas sebesar $14952 \mathrm{~Pa}$.

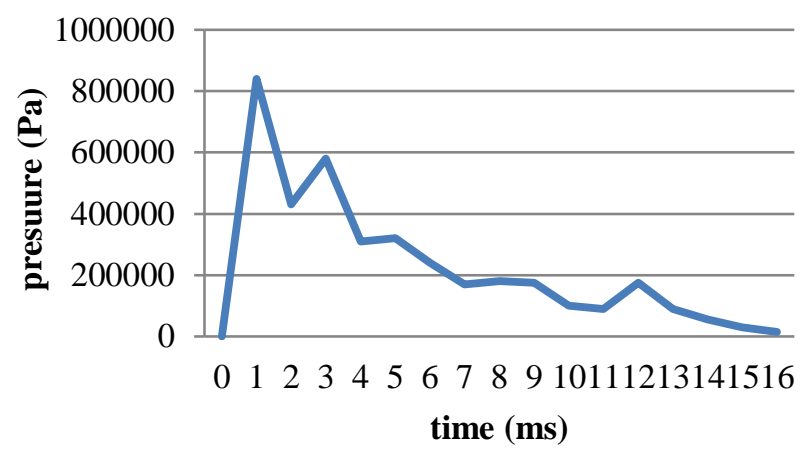

Gambar 4. Grafik Stress Terhadap Waktu dari Data Komputasi dengan sumbu x adalah waktu dan sumbu y adalah tegangan

Data yang didapat setelah komputasi dan eksperimental pada waktu $16 \mathrm{~ms}$ sebagai berikut :

Tabel 4 Pembandingan Tegangan Eksperimental dengan Komputasi

\begin{tabular}{cc}
\hline Pengujian & Tegangan yang Terjadi $\sigma(\mathrm{MPa})$ \\
\hline Eksperimental & 14231 \\
Komputasi & 14952 \\
\hline
\end{tabular}

Data komputasi yang didapat dibandingkan dengan data eksperimental untuk sebagai data validasi data yang akan digunakan menjadi basis penentuan data.Nilai yang diambil adalah nilai yang didapat pada waktu $16 \mathrm{~ms} . \quad \%$ Galat $=\frac{14952-14231}{14952} * 100 \%=4,82 \%$

Setelah dilakukan perhitungan diperoleh \%galat antara data komputasi dengan data eksperimental berupa $4,82 \%$. Untuk itu data ini akan digunakan sebagai acuan atas gaya yang terjadi pada spesimen.

Dari nilai yang kita dapat bahwa tegangan rata-rata pada spesimen adalah $305251 \mathrm{~Pa}$ yang berarti menyimpan gaya sebesar $14,95 \mathrm{kN}$. Kemudian hasil tersebut dibandingkan dengan produk pelindung dada yang dijual di pasaran yaitu LEATT 5.50 yang terbuat dari bahan High Density Poly Ethylene dengan modulus elastisitas $0,8 \mathrm{Gpa}$ dan densitas $970 \mathrm{~kg} / \mathrm{m}^{3}$. 5:

Data hasil komputasi dibandingkan data standarisasi pelindung dada dapat dilihat pada Tabel

Tabel 5 Pembandingan Transmisi Gaya

\begin{tabular}{cccc}
\hline $\begin{array}{c}\text { Transmisi } \\
\text { Gaya }\end{array}$ & $\begin{array}{c}\text { Standar } \\
\text { EN }\end{array}$ & $\begin{array}{c}\text { LEATT } \\
\text { Imp0 }\end{array}$ & Spesimen \\
Impak & $1621-3$ & $\begin{array}{c}\text { PRO } \\
\text { LITE }\end{array}$ & \\
\hline $\begin{array}{c}\text { Rata- } \\
\text { Rata(kN) }\end{array}$ & $<20$ & 12.1 & 14.95 \\
$\begin{array}{c}\text { Maksimum } \\
(\mathrm{kN})\end{array}$ & $<35$ & 22.7 & $\mathbf{2 9 . 1 8}$ \\
\hline
\end{tabular}


Data komputasi yang digunakan adalah data komputasi pada saat tegangan maksimum,dan data komputasi menunjukkan transmisi gaya impak spesimen yang tidak melampaui data pada standarisasi yang ada.

\section{KESIMPULAN}

a. Dari hasil pengujian jatuh bebas pada material Polyester Polymer diketahui bahwa material ini tidak mampu menerima gaya impak sebesar $627,45 \mathrm{~N}$ dan tegangan sebesar 0,012 MPa sehingga tidak cocok digunakan sebagai material pelindung dada.

b. Dari hasil pengujian jatuh bebas pada material PolyesterPolymer Sandwich EVA Foam diketahui bahwa material ini masih berbentuk utuh ketika menerima gaya impaksebesar 742,42 $\mathrm{N}$ dan tegangan sebesar 0,015 MPa tetapi terjadi keretakan pada spesimen sehingga terdapat risiko material yang retak tersebut dapat menusuk pemakainya.

c. Dari hasil pengujian jatuh bebas pada material Glass Fibre Reinforced Polymer diketahui bahwa material ini masih berbentuk utuh ketika menerima gaya impak sebesar 698,17 Ndan tegangan sebesar 0,014 MPa tetapi untuk menyatukan bahan ini ke busa EVA dapat menyebabkan penyusutan dan pemadatan pada rompi busa EVA.

d. Dari hasil pengujian jatuh bebas pada materialGlass Fibre Reinforced Polymer Sandwich EVA Foam diketahui bahwa material ini tidak terjadi perubahan bentuk ketika menerima gaya impak sebesar 769,79 $\mathrm{N}$ dan tegangan sebesar 0,015 MPa. Bagian bawah plat komposit ini terdiri dari busa EVA sehingga mudah disatukan dengan rompi busa EVA.

1. Perbandingan data eksperimental dengan komputasi memiliki galat sebesar $4,82 \%$

2. Dari hasil uji eksperimental dan komputasididesain produk ini dengan spesifikasi Glass Fibre Reinforced Polymer Sandwich EVA Foam dengann kemampuan menahan gaya impak sebesar 769,79 N. Bentuk plat komposit dibuat trapesium agar memudahkan gerakan lengan pemakainya yang posisi penyatuannya terletak di bagian tulang rusuk.Pelindung dada juga dapat di atur ukurannya karena menggunakan perekat velcro.

\section{DAFTAR PUSTAKA}

[1] Chawla,A., Mukherjee,S., Mohan, D.,Bose, Bose,D.,Rawat,P. 2001. FE Simulations of Motorcycle - Car Frontal Crashes, Validaton and Observations. Indian Institute of Technology. http://tripp.iitd.ernet.in/publications/paper/biomech/18ESV-FEsimul.pdf diakses tgl 03-102013 jam 11:00 WIB

[2] Spesifikasi produk Chest Protector LEATT PRO LITE. http://www.leattbrace.com/product_uploads/ce_certificates/CHEST\%20PROTECTOR\%20LEATT\%205.5\%20 PRO\%20LITE.pdf diakses tgl 13-05-2014 jam 13:00 WIB

[3] http://www.highvelocitygear.com/ diakses tgl 13-05-2014 jam 13:10 WIB

[4] http://www.satra.co.uk/spotlight/article_view.php?id=190 diakses tgl 14-05-2014 jam 14:30 WIB

[5] Glass Fibre Reinforced Product for Industrial Applications. Amitech Industrial.http://www.amiantit.com/media/pdf/brochures/Glass_Fibre_Reinforced_Products/ files/Glass_Fibre_Reinforced_Products.pdf diakses tgl 14-05-2014 jam 15:15

[6] Material Data Book.2003. Cambridge University Engineering Departement. http://wwwmdp.eng.cam.ac.uk/web/library/enginfo/ cueddatabooks/materials.pdf diakses tgl 14-05-2014 jam 15:10

[7] Lagrangian equation . http://scienceworld.wolfram.com/physics/Lagrangian.html diakses tanggal 06-03-2014 jam 20:30

[8] Chapter 1: Lagragian Mechanic.www.ks.uiuc.edu/Services/Class/PHYS480/qm_PDF/chp1.pdf. diakses pada tanggal 06-03-2014 jam 21.00 